\title{
Efficacy of biocontrol agents against Sclerotium rolfsii causing collar rot disease of chickpea, under in vitro conditions
}

\author{
- GOWDRA NAGAMMA* AND A. NAGARAJA ${ }^{1}$
}

Department of Plant Pathology, University of Agricultural Sciences, G.K.V.K., BANGALURU (KARNATAKA) INDIA ${ }^{1}$ Project Co-ordinating Unit (Small Millets), ICAR, G.K.V.K., BANGALURU (KARNATAKA) INDIA

\section{ARITCLE INFO}

Received : 13.04 .2015

Revised : 18.07 .2015

Accepted : 03.08 .2015

\section{KEY WORDS :}

Chickpea, Collar rot, Sclerotium rolfsii, Biological control, Trichoderma
*Corresponding author:

Email: nagamma0239@gmail.com

\begin{abstract}
Chickpea is known in this country since ancient times. It is a widely grown major pulse crop in India, accounts for nearly 75 per cent of the total pulse production in the world. Chickpea crop is prone to many diseases. Among them, collar rot caused by Sclerotium rolfsii which is gaining importance. $S$. rolfsii is a soil borne plant pathogen causing root rot, stem rot, collar rot, and foot rot diseases on more than 500 plant species of agricultural and horticultural crops throughout the world. Most of the first symptom associated with S. rolfsii are usually yellowing and wilting of leaves following collar rot infections. Pathogenecity was proved by Koch's postulates. Biological management of the disease through antagonists is an eco-friendly approach apart from better alternative to the use of chemicals. In the present study, the nine antagonistic microorganisms were evaluated by dual culture technique for their antagonistic effect against S. rolfsii under in-vitro conditions. Maximum inhibition of mycelial growth $(71.67 \%)$ was noticed in T. harzianum (Bacteriology lab isolate) which was followed by T. viride (Microbiology lab) (63.33\%). Least inhibition was observed in T. harzianum GKVK isolate (31.67\%). The results indicated that the application of these micro-organisms successfully decreases the stem rot incidence and also increases the growth of the chickpea plants.
\end{abstract}

How to view point the article : Nagamma, Gowdra and Nagaraja, A. (2015). Efficacy of biocontrol agents against Sclerotium rolfsii causing collar rot disease of chickpea, under in vitro conditions. Internat. J. Plant Protec., 8(2) : 222-227. 